\title{
Synthesis of BMS-741672
}<smiles>COC(=O)[C@H]1CC=CC[C@H]1C(C)=O</smiles>

$\mathrm{PhH}, \Delta, 2.5 \mathrm{~h}$

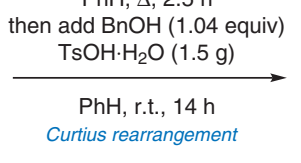<smiles>COC(=O)[C@@H]1CC=CC[C@H]1C(=O)O</smiles>

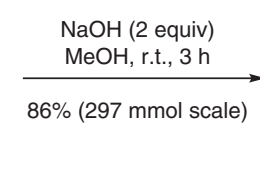<smiles>CC(=O)N[C@H]1CC=CC[C@H]1C(=O)O</smiles>
mp $129-134^{\circ} \mathrm{C}$<smiles>CC(C)(C)OC(=O)N[C@H]1CC[C@@H]2C[C@H]1C(=O)N2C(=O)OCc1ccccc1</smiles>
$\frac{\begin{array}{c}\mathrm{Bu}_{3} \mathrm{SnH}(1.1 \text { equiv) } \\ \mathrm{AlBN}(0.05 \text { equiv) }\end{array}}{\begin{array}{c}\mathrm{PhH}, \Delta, 66 \mathrm{~min} \\ 91 \%(76 \mathrm{mmol} \text { scale })\end{array}}$

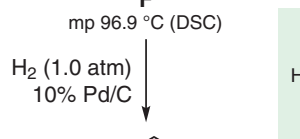<smiles>CC(C)(C)OC(=O)N1C[C@@H]2CC[C@@H](N)[C@H]1C2=O</smiles>

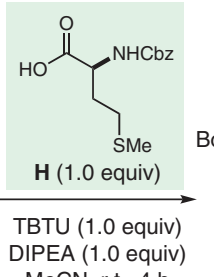
mp $184,194^{\circ} \mathrm{C}$ (DSC)

n-BuLi (1.0 equiv)

then add $\mathrm{I}_{2}$ (3 equiv) $52 \%(6.9 \mathrm{~mm}$ 2 steps $\downarrow 56 \%$

\section{Category}

Synthesis of Natural

Products and

Potential Drugs

\section{Key words}

BMS-741672

Hoffman

rearrangement

Curtius

rearrangement

iodolactamization

1,2,4-triamino-

cyclohexanes

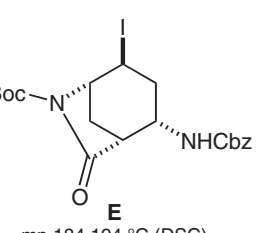

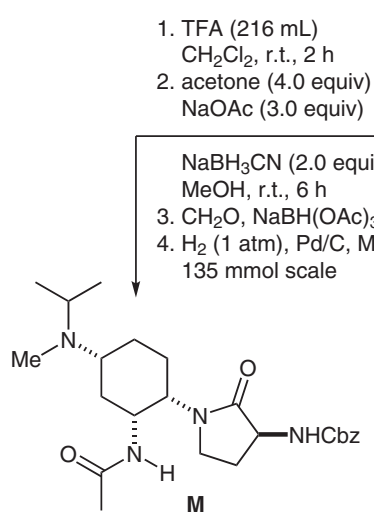

1. TFA $(216 \mathrm{~mL})$

acetone ( 4.0 equiv)

$\mathrm{NaBH}_{3} \mathrm{CN}$ (2.0 equiv)

.

BocHN, ,<smiles>CC1CCCCC1</smiles><smiles>CCNC(C)=O</smiles><smiles>C=C1CN(C)CC1NC(=O)O</smiles><smiles>CC(=O)OC(C)(C)OC(=O)N[C@H]1CC=CC[C@H]1C(=O)OCc1ccccc1</smiles>
mp $124.6^{\circ} \mathrm{C}$ (DSC)

\section{Synifacts}

Significance: BMS-741672 is a chemotactic chemokine receptor 2 (CCR2) antagonist that is of interest for the treatment of inflammatory, cardiovascular, and metabolic diseases. The discovery synthesis depicted (>20 steps) is based on construction of the all-cis 1,2,4-triaminocyclohexane core using a Curtius rearrangement $(\mathbf{A} \rightarrow \mathbf{B})$, an iodolactamization $(\mathbf{D} \rightarrow \mathbf{E})$, and a Hoffman rearrangement $(\mathbf{K} \rightarrow \mathbf{L})$.
Comment: The synthesis of lactam $\mathbf{G}$ was previously developed by Bristol-Myers Squibb (C. L. Campbell et al. J. Org. Chem. 2009, 74, 6368), and a shorter large-scale route to BMS-741672 was subsequently reported that delivered $50 \mathrm{~kg}$ of API for clinical evaluation (J. Deerberg et al. Org. Process Res. Dev. 2016, 20, 1949). 